\title{
Building research capacity among a group of social media adopters in Canada: introducing the Social Media Research Team (SMeRT)
}

\section{Dean Giustini}

\section{Introduction}

We tried every social media application you can think of. Some worked, some didn't. [1]

This is the second installment of a new column on social media for JCHLA / JABSC. Here, I provide an overview of an exciting new social-media venture that originated at the University of British Columbia (UBC) in the summer of 2010 and brought together interested professional academic librarians and MLIS students from across Canada. The venture is called the Social Media Research Team (SMeRT) [2] and the team's primary goals are to share information and find new ways to collaborate on research. Currently, SMeRT consists of librarians who are either studying librarianship or working in public or academic libraries from coast to coast (from Vancouver, British Columbia to Halifax, Nova Scotia):

- Tania Alekson, Librarian, Capilano University Library, North Vancouver, B.C.

- Amy Ashmore, MLIS student, UBC School of Library, Archival and Information Studies, Vancouver, B.C.

- Allan Cho, Program Services Librarian, Irving K. Barber Learning Centre, UBC, Vancouver, B.C.

- Dean Giustini, UBC Biomedical Branch Librarian, UBC Library, Vancouver, B.C.

- Daniel Hooker, Health Librarian, MLIS

- Xuemei Li, Digital Librarian, Patrick Power Library, Saint Mary’s University, Halifax, N.S.

This Canadian research team consists of librarians who have expressed interest in using and evaluating social media for the delivery of library services. One subgroup consists of recent graduates from UBC's School of Library, Archival and Information Studies (SLAIS) who have completed internships involving digital media and library 2.0 [3-7]. A second subgroup recently completed either a directed study about social media or a relevant course such as LIBR559M, Social media for information professionals offered by SLAIS [8-9]. In 2009 the instructor of that course identified several ideal topics for Canadian researchers. Subsequently, he wrote an application for a grant from the Canadian Association of Research Libraries (CARL / ABRC) and received start-up funding. The research goal is to gather information on behaviours and attitudes of Canadian academic librarians who are using social media and to look at the personal, technical, and professional barriers that are preventing the adoption of social media. To start, one of the aforementioned SLAIS students, Amy Ashmore, was hired and later took a course on social media. Together, we began work on an environmental scan of the website of Canadian academic libraries to assess how these libraries were using social media. A literature review was completed of Canadian academic librarians' use of social media was completed, and websites were examined for examples; the environmental scan was published on SlideShare in August 2010 [10]. The inventory of social media usage in Canadian academic libraries is a foundation for our project. Our next steps are to develop and validate a survey questionnaire and carry out a pilot and full release in fall 2010 [11].

\section{Diverse interests, collaborative practices}

The SMeRT librarians have wide interests pertaining to social media and have identified a number of research areas that are of interest. First and foremost, however, we have come together to share our ideas and to build a supportive, collaborative network [2]. Many of us are new to research and realize that we need to build our skills and capacity over time. We recognize the challenges in getting started as a trans-Canadian group outside of the contexts of our regular library work. In fact, the literature suggests that the exploration of social media tools is a very time-consuming activity and the lack of evaluation tools creates other problems. Undaunted, we would like to eventually solve the problem of a lack of evaluation tools but to begin with, we have created a research portal on the HLWIKI Canada to centralize resources for SMeRT members who want to learn more about conducting rigorous library and information (LIS) research (see http://hlwiki.slais.ubc.ca/index.php/ Research_for_librarians_-_portal).

The SMeRT librarians are at different stages in their professional development. Many use social media habitually

D. Giustini. Biomedical Branch Library, Gordon and Leslie Diamond Health Care Centre, University of British Columbia, 2775 Laurel Street, Floor 2, Vancouver, BC V5Z 1M9, Canada (email: dean.giustini@ubc.ca). 
and blog and tweet daily. As much as possible, we enjoy the fun of sharing ideas using traditional email, our blog (http://smertlibrarians.wordpress.com/), SlideShare (http://slideshare.net/smertlibrarians PowerPoint slides and presentations), and Twitter (http://www.twitter.com/ smertlibrarians). Our philosophy can be summed up as "to share is to learn" (our blog tagline). Sharing is an important trigger for learning and collaboration; despite sharing information in the digital spaces already mentioned, we are thinking about coordinating our activities in a separate network created on Ning (http://www.ning. $\mathrm{com} /$ ) or the dashboard tool called Netvibes (http://www. netvibes.com/en). We are open to other ideas and welcome anyone who may be interested in sharing their knowledge with us.

\section{Emphasis on media literacies}

Keep up with the literacies [of social media] ...not the technologies [12]

The SMeRT librarians have been working on several research projects that involve the promotion of social media and keeping up with the literacies needed to use social media properly. Living in a world where change seems to occur in real-time, the ability to discover, analyze, and revise our information practices (and our users') is central to our thinking. By evaluating social media, we are continually developing new ways to improve our own current awareness tools and literacies. The rise of social media and the transformation of the web from a broadcast (one-to-many) to collaborative (many-to-many) medium changes how librarians engage in lifelong learning and information literacy [13]. While some librarians working in academic institutions say that social networking has minimal application, others say that new technologies are central to building professional new skills in the domain of information literacy. We see many popular social media tools such as Facebook, LinkedIn, and Twitter have surpassed their original, intended (and limited) affordances; they have become platforms for learning. We consider the application of social media in the broadest sense of being "social" since librarianship includes many social forms of informal learning and interaction. We firmly believe in the social aspects of learning and its importance in promoting information and media literacies in the digital age.

\section{Conclusion}

Looking to the future, social media is a part of everyone's work in libraries. Social tools continue to be used in innovative ways but are disruptive to our traditional methods of service provision. In other words, how will we maintain our traditions of service in the face of so many online tools? This is a fundamental question for librarians working in the social media age. Several SMeRT librarians are looking for solutions and developing best practices involving social media: Xuemei Li in Halifax, for example, is exploring social bookmarking sites as a way to determine the influence of scholarly papers; Dean Giustini is evaluating reference management tools such as Mendeley and Zotero; Daniel Hooker is examining the use of mobile devices and social media in his work with the UBC Faculty of Medicine; Allan Cho and Dean Giustini have written a book chapter about web 3.0 [14]; Xuemei Li and Dean Giustini are currently working on a study of bibliometric data culled from social websites as a means of measuring scholarly influence; and Amy Ashmore, Daniel Hooker, and Dean Giustini have been invited to present their thoughts about SMeRT at a fall meeting of the Health Libraries Association of British Columbia. Through the various social media tools mentioned, we hope to keep you apprised of our research in the year ahead as we examine the effects of social media on our field.

\section{References}

1. Wesch M. The Machine Is Us/ing Us. 2008. [slideshare document] Available from: http://www.slideshare.net/Jaeya/themachine-is-us-ing-us-presentation-862567

2. Alekson T, Giustini D. Collaborative academic librarians in Canada: introducing the social media research team (SMeRT). [slideshare document]. 2010 August 15. Available from: http:// www.slideshare.net/giustinid/s-me-rt-librarians-2010

3. Alekson T, Bezanson M, Li X. Pitching student savvy: Web 2.0 workshop development in higher education. BCLA Conference, Burnaby, BC, 2009 April 16-18.

4. Alekson T. Historical collections 2.0: from information to understanding. Library 3.0: student views. Canadian Association of Special Libraries and Information Services (CASLIS), Oct 2008.

5. Alekson T, Li X, Cho A. Digital media internships: LIS education 2.0. (poster) Meeting of the American Society for Information Science and Technology, Vancouver, BC, 2009.

6. Cho A. Social media in academic libraries. Social media in the workplace: Current Trends and Work Practices. Special Libraries Association (SLA), Western Canada Chapter. Vancouver, BC, 2009 Dec 3.

7. Hooker D. What is Twitter? Or, how to stop worrying and love to tweet. Tools for Outreach and Teach Session (TOTS), University of British Columbia Library. Vancouver, BC. December 1, 2009. [slideshare document]. 2010 Aug 15. Available from: http://www.slideshare.net/danhooker/what-is-twitter-orhow-to-stop-worrying-and-love-to-tweet

8. Hooker D. Social media adoption, policy and development: Exploring the way forward for academic libraries.). [slideshare document]. 2010 Aug 15. In completion of the requirements for LIBR 594: Directed Study at the School of Library, Archival and Information Studies (SLAIS). University of British Columbia. 1 December 2009.

9. Giustini D. LIBR559M: Social media for information professionals. Course syllabus. Available from: http://hlwiki.slais.ubc. ca/index.php/LIBR_559M_-_Social_Media_for_Information_ Professionals

10. Ashmore A, Giustini D. A preliminary environmental scan of social media usage in CARL/ABRC libraries.). [slideshare document]. 2010 Aug 15. Available from: http://www.slideshare. net/giustinid/carl-abrc-social-media-enrivonmental-scan-2010

11. Giustini D. Survey of Canadian academic librarians \& their use of social media (2010-2011). HLWIKI Canada. 
Available from: http://hlwiki.slais.ubc.ca/index.php/Survey_ of_Canadian_academic_librarians_\%26_their_use_of_social_ media_\%282010-2011\%29

12. Rheingold $\mathrm{H}$. Using participatory media and public voice to encourage civic engagement. In: WL Bennett. 2008. Civic life online: learning how digital media can engage youth. Cambridge, MA: MIT Press, 97-118.
13. Giustini D. All health librarians need web 2.0 skills. J Can Health Libr Assoc. 2010;(31):73-75.

14. Cho A, Giustini D. Web 3.0 and health librarians: what does the future hold? Preprint of a book chapter for Facet publishing, 2010.) [slideshare document]. 2010 Aug 15. Available from: http://www.slideshare.net/giustinid/web-30-and-healthlibrarians-chapter-facet-2010 